\title{
Exploring the Knowledge Level of Interior Architecture and Environmental Design Students' on Indoor Air Pollutants
}

\author{
lç Mimarlık ve Çevre Tasarımı Bölümü Öğrencilerinin \\ iç Hava Kirleticileri Ille Illgili Bilgi Düzeylerinin Belirlenmesi
}

Feray ÜNLÜ, ${ }^{1}$ Kemal YILDIRIM²

\section{ABSTRACT}

This study aimed to detect the knowledge levels of the final year students, attending at the Department of Interior Architecture and Environmental Design of various universities in Turkey, on the harmful effects of the pollutants released by the interior equipment elements on human health. A detailed questionnaire developed for this purpose was administered to 95 final year students attending at the Department of Interior Architecture and Environmental Design of Atlım University, Hacettepe University and Selçuk University. In conclusion, the study found that the participants had insufficient knowledge on the pollutants released by the interior equipment elements and that knowledge level of the participant students differed depending on the attended university. This difference may have resulted from the difference of the share of indoor air pollutants subject in the programs of the three selected universities. These results clearly point the need to allocate more space to the subject of indoor air pollutants -which have direct effects on human health- in the compulsory lesson contents of the course programs. By this way, it will be possible to educate interior architects and environmental designers who develop more sensitive and conscious approach towards human health.

Keywords: Environmental systems; human health; indoor air pollutants; interior architecture education; interior design.

\section{Öz}

Bu çalışmada, Türkiye'deki üniversitelerin iç Mimarlık ve Çevre Tasarımı Bölümü son sınıf öğrencilerinin iç mekân donatı elemanlarından ortama yayılan kirleticilerin insan sağlığı üzerindeki zararlı etkileri hakkındaki bilgi düzeylerinin belirlenmesi amaçlanmıştır. Bu amaçla geliştirilmiş olan ayrıntılı bir anket; Atılım, Hacettepe ve Selçuk Üniversiteleri iç Mimarlık ve Çevre Tasarımı Bölümlerinin son sınıfinda mezuniyet durumunda bulunan 95 öğrenciye uygulanmıştır. Sonuçta, katılımcıların iç mekân donatı elemanlarından ortama yayılan kirleticiler hakkındaki bilgilerinin yeterli düzeylerde olmadığı ve mezun adaylarının bilgi düzeylerinin üniversitelere göre farklılıklar gösterdiği tespit edilmiştir. Bu farklılıklar, her üç üniversitenin ders programlarında iç hava kirleticileri hakkındaki bilgilerin yer alma oranlarından kaynaklanmış olabilir. Bu sonuçlar, insan sağlığına doğrudan etkisi olan bu kirleticilerin ders programlarında zorunlu ders içeriklerinde daha fazla yer verilmesi gerektiğini açıkça ortaya koymuştur. Böylece insan sağlığına daha bilinçli ve duyarlı yaklaşan iç mimar ve çevre tasarımcıları yetiştirilebilecektir.

Anahtar sözcükler: Çevre sistemleri; insan sağlığı; iç hava kirleticileri; iç mimarlık eğitimi; iç mekân tasarımı.

'Department of Interior Architecture and Environmental Design, Faculty of Fine Art, Design and Architecture, Atılım University, Ankara, Turkey ${ }^{2}$ Department of Furniture and Decoration, Faculty of Technical Education, Gazi University, Ankara, Turkey. 


\section{Introduction}

Preferences, policies and material choices of the decision-makers who play an active role in building construction process may result in health problems for the users of these buildings. Construction of a healthy building requires elimination of negative effects on building-user-environment system. For this reason, building materials play a key role in construction of healthy buildings. Selection of wrong materials increases interior pollutants which have negative effects on human health. Reports issued by the World Health Organization (WHO) announces that people spend $90 \%$ of their time in closed spaces. ${ }^{1}$ In this scope, indoor air quality becomes as important as outdoor air quality. Many scientific studies on this issue emphasize negative effects on human health of the pollutants released to the medium by interior equipment elements. ${ }^{2}$

In the study made by Yildirim and Ünlü in Ankara, indoor space users in Turkey were detected to have insufficient knowledge about organic chemicals released to the medium by equipment elements. According to the concerned study, age factor is related to the level of knowledge about this issue: young people ages between 18-29 have lower level of knowledge about the organic chemicals released to the medium by interior equipment elements than the middle-aged group who are $30+$ age range. ${ }^{4}$ Taking into consideration the age assortment of university students in Turkey and the fact that candidate designers are also in this age range; this results raises the question whether or not the knowledge of candidate designers about gases released by organic chemicals as well as other indoor air pollutants released to the medium by the materials used in construction, is dependent on curriculum of interior architecture and environmental design departments. From this point of view, present study attempted to reveal the knowledge level of the university students receiving interior architecture and environmental design education about the indoor air pollutants directly effecting public health.

Building and interior equipment elements as well as user requirements have been affected in qualitative and quantitative terms by the technological developments recorded since the Industrial Revolution. As a result, designer responsibilities related to product selection have increased in direct proportion. Due to the

\footnotetext{
1 Pearson, 1989, Yıldırım, 2013 and Yildirim and Ünlü, 2013.

2 Wolverton et al., 1984, Wolverton et al., 1989, Pearson, 1989

Gökbel and Uzun, 1995, Johnson and Hill, 2002, Vural and Balan-

II, 2005, Çobanoğlu and Kiper, 2006, Yurtseven, 2007, Çimen and Öztürk 2010 and T.C. Sağlık Bakanlığı, 2010.

Yildirim and Ünlü, 2013.

Yildirim and Ünlü, 2013.
}

changes in the production and application techniques of building products, deciding on the use of right and healthy product now requires sufficient knowledge level. Assumption that curriculum of the Interior Architecture and Environmental Design Departments offer limited number of courses to develop knowledge on the subject that students have insufficient knowledge about the pollutants released to the medium by interior equipment elements so this crease an important problem threatening user health. Considering that interior designers acquire this knowledge during their university education, courses focusing on environment and building interaction turn out to be more important as the students receiving such education will be the ones who will make interior design in the future when they will have to make material selection decisions which will affect human health positively. From this viewpoint, this study aimed to reveal the knowledge level of final year students -graduation candidates attending at Interior Architecture and Environmental Design Departments of three different universitiesabout harmful indoor air pollutants directly affecting community health. To this end, contents of the courses offered by the three universities included in the study scope were analyzed in the first phase of the study are production, application, usage, maintenance, repair, renewal, recycling, disposal, sustainability, effects on indoor air quality of the building materials as well as the relationship between health and indoor air; and laws, regulations and directives on these issues. In the second phase of the study, the questionnaire administered to the graduation candidates of the three universities to measure their knowledge level about indoor air pollutants was evaluated.

\section{Indoor Air Pollutants and Their Effects on Health}

Different types of various air pollutants can be present interior spaces. Indoor air pollutants addressed in this study are the pollutants released to the medium by interior equipment and materials which are taught during the courses covered by the study. Indoor air pollutants were limited to the information taught in these courses and the questionnaire items were limited to the reinforcements and materials used most among those taught in these courses. According to the classification made by the Ministry of Health of the Republic of Turkey ${ }^{5}$, these pollutants are bio-aerosols (bacteria, fungi, fungal spores, viruses, pollen and all organic dust containing the particles of these bio-aerosols), tiny particular materials (particles created by

\footnotetext{
5 T.C. Sağlık Bakanlığı, 2010.
} 
combustion of diesel fuels, cigarette smoke, fired-up stove or cooking), volatile organic substances (formaldehyde, xylene, toluene, ethylbenzene, benzene, trichloroethylene, etc.), pesticides (pesticides and other chemical materials killing fungi and bacteria), pollutant gases (carbon dioxide, carbon monoxide, ozone, sulfur dioxide, nitrogen oxides, asbestos and radon $)^{6}$ and radiation. ${ }^{7}$

US Environmental Protection Agency (EPA) states that indoor air pollution is 2 to 10 times higher than outdoor air pollution. ${ }^{8}$ One of the factors effective on indoor air quality is outdoor air pollution. ${ }^{9}$ Building materials have a direct effect on indoor air quality. When the pollutants released to the medium by the interior equipment elements are added to this, there arise inevitable negative effects on human health. Symptoms related to building are called "sick building syndrome". ${ }^{10}$ Most important reasons of sick building syndrome are insufficient ventilation conditions arising in heat-insulated buildings and chemical and microbiological pollution resulting from selection of wrong materials. In sick building syndrome, negative effects are observed to develop in 15-30 minutes to a few hours after entrance into interior space and to disappear in 30 minutes to a few hours after leaving the building. ${ }^{11}$ World Health Organization (WHO) listed in 1982 the symptoms of this syndrome as follows: eye, nose and throat irritation; neurological and general health symptoms such as headache, dizziness, nausea, vomiting, physical and psychological exhaustion and memory loss; skin irritations such as redness, pain, itching and dryness of skin; oversensitivity reaction with no specific reason: asthma-alike symptoms in people without asthma, such as runny eyes and nose; and changes in the senses of smell and taste. ${ }^{12}$

Some diseases to develop due to microbiological factors, can be clinically associated with building. Such diseases are defined by the term "building-related illnesses (BRIs)". Legionnaires' disease, asthma, hypersensitive pneumonitis, moisturizing temperature and chronic allergic rhinitis can be listed as building-related illnesses. ${ }^{13}$

Indoor air pollution caused by the use of solid fuel can be generally held responsible for death from phenomena, chronic respiratory system diseases and lung cancer. In developing countries with high mortality

\footnotetext{
T.C. Sağlık Bakanlığı, 2010. Yildirim and Ünlü, 2013.

Ohura, 2009.

Vaizoğlu et al., 2000.

${ }^{10}$ Levins, 1996.
}

\footnotetext{
11 Maroni et al., 1995, Oahn and Hung, 2005 and Spellman, 2008.

${ }^{12}$ Spellman, 2008 and Chang et al., 1993.

${ }^{13}$ T.C. Sağlık Bakanlığı, 2010.
}

rates, smoke in interior environment is one of the most important reasons of death. ${ }^{14}$ On one hand there has been a relationship between the level of air pollution caused by particular substances, on the other hand respiratory track diseases and lung function, heart and respiratory track problems and related death cases. ${ }^{15}$ Regular exposure to volatile organic components and formaldehyde may cause cancer and high concentrations of these substances may cause even coma and death. Chronic exposure to specific pesticides (bacteria, fungi and other organisms) may damage liver, kidneys and neural system and increase the risk of cancer. ${ }^{16}$

\section{Theoretical Infrastructure}

According to the "environmental systems" explanation offered in Standard 12 of "Professional Standards 2014" issued by the Council for Interior Design Accreditation (CIDA), interior design students should have knowledge about improvement of air-conditioning comfort, healthy indoor air quality and building performance. Course contents should offer information on the principles related to indoor air quality and how the products and systems effective on air quality manage this; polluting-source control; filtration; ventilation variables; $\mathrm{CO}_{2}$ emission; and prevention of mold formation. ${ }^{17}$ In this framework, Interior Architecture and Environmental Design Departments of the three universities studied were analyzed in detail, by taking into consideration course types and contents, in terms of the extent to which the subject of "pollutants with negative impact on indoor air quality" is reflected to the curriculum.

Firstly, compulsory and elective courses studying the same content, under different names though, offered the curriculum of the Interior Architecture and Environmental Design Departments of all three study universities were classified according to CIDA Standards and are presented in Table 1. Project production courses were excluded from the study scope due to the fact that a different project on a different issue was studied each education semester and education year and the information offered in relation to indoor air quality was included in the contents of supportive courses. Information on indoor air pollutants given in the course groups classified above should be offered in related courses. Indoor air pollutants, building products releasing these pollutants and their effects on

\footnotetext{
${ }^{14}$ Krzyzanowski and Cohen, 2008 lığı, 2010. and T.C. Sağlık Bakanlığı, 2010. $\quad{ }^{16}$ T.C. Sağlık Bakanlığı, 2010.

${ }^{15}$ Brunekreef and Holgate, 2002, ${ }^{17}$ CIDA, 2014. EPA, 2004 and T.C. Sağlık Bakan-
} 
health envisaged to be taught in these courses were included in the present study after compiled from the references by the study authors, in order to contribute to the subject.

According to Table 1, 7 compulsory and 8 elective courses were offered by Atlım University, 8 compulsory and 6 elective courses were offered by Hacettepe
University and 10 compulsory and 8 elective courses were offered by Selçuk University in the study period, in relation to the effects on human health of the pollutants released to the medium by the interior equipment elements. Considering that students did not take all elective courses presented in Table 1, it would be better to seek sufficient level of knowledge in the con-

Table 1. Contents of the courses taught in Interior Architecture and Environmental Design Departments

\begin{tabular}{|c|c|c|c|}
\hline $\begin{array}{c}\text { Course } \\
\text { Classification }\end{array}$ & $\begin{array}{c}\text { Atılım University } \\
\text { Interior Architecture and } \\
\text { Environmental } \\
\text { Design Department }\end{array}$ & $\begin{array}{c}\text { Hacettepe University } \\
\text { Interior Architecture and } \\
\text { Environmental } \\
\text { Design Department }\end{array}$ & $\begin{array}{c}\text { Selçuk University } \\
\text { Interior Architecture and } \\
\text { Environmental Design } \\
\text { Department }\end{array}$ \\
\hline 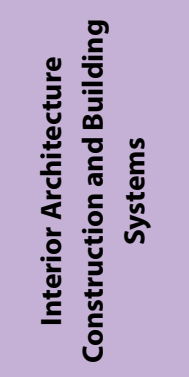 & $\begin{array}{l}\text { - Construction and Materials I } \\
\text { - Construction and Materials II } \\
\text { - Building and Structure } \\
\text { - Climatic Comfort, } \\
\text { Passive and Mechanical } \\
\text { Systems* } \\
\text { - Wet Place Design }\end{array}$ & $\begin{array}{l}\text { - Interior Construction Methods I } \\
\text { - Interior Construction Methods II } \\
\text { - Structure Knowledge } \\
\text { - Interior Environmental } \\
\text { Control Systems* }\end{array}$ & $\begin{array}{l}\text { - Material Knowledge I } \\
\text { - Material Knowledge II } \\
\text { - Interior Construction Knowledge } 1 \\
\text { - Interior Construction Knowledge II } \\
\text { - Sanitation System } \\
\text { - Heating Ventilation* } \\
\text { - Structure Knowledge } \\
\text { - Building Knowledge/Modern Stone } \\
\text { Systems }\end{array}$ \\
\hline 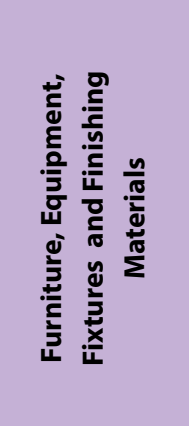 & $\begin{array}{l}\text { - Furniture Design } \\
\text { - Modular Systems } \\
\text { - Detail Design }\end{array}$ & $\begin{array}{l}\text { - Furniture Manufacturing } \\
\text { Methods I } \\
\text { - Furniture Manufacturing } \\
\text { Methods II } \\
\text { - Furniture Design I } \\
\text { - Furniture Design II } \\
\text { - Modern Furniture Design } \\
\text { - Flexibility in Design } \\
\text { - Furniture Material and } \\
\text { Application Method }\end{array}$ & $\begin{array}{l}\text { - Equipment Design } \\
\text { - Design of City Furniture }\end{array}$ \\
\hline 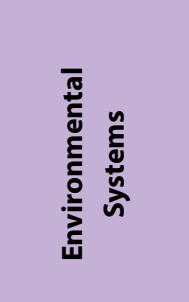 & $\begin{array}{l}\text { - Introduction to Landscape } \\
\text { Design } \\
\text { - Design of City Furniture } \\
\text { - Principles of Ecological } \\
\text { Design } \\
\text { - Applied Ecological Design } \\
\text { - Introduction to Urban Design }\end{array}$ & $\begin{array}{l}\text { - Sustainable Design } \\
\text { - City and Space }\end{array}$ & $\begin{array}{l}\text { - Introduction to Environmental } \\
\text { Design/Environmental Knowledge -I } \\
\text { - Environmental Knowledge II/ } \\
\text { Environmental Design Project } \\
\text { - Botanic Design I } \\
\text { - Botanic Design II } \\
\text { - Health Structure }\end{array}$ \\
\hline 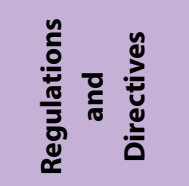 & $\begin{array}{l}\text { - Building Management } \\
\text { - Legal Framework of Building } \\
\text { Production }\end{array}$ & $\begin{array}{l}\text { - Professional Application } \\
\text { Knowledge }\end{array}$ & $\begin{array}{l}\text { - Structural Discovery } \\
\text { - Cost/Business Law I } \\
\text { - Marketing/Business Law II }\end{array}$ \\
\hline
\end{tabular}


tent of compulsory courses. Contents of these courses were analyzed in terms of pollutants penetrating indoor air and their harmful effects on health, under the four titles given below.

\section{Analysis of the Courses on Construction and Building Systems}

This group includes courses on building systems, construction, structure, construction and materials, heating, ventilation and sanitation system. Materials mentioned during these courses are explained below in relation to indoor air pollutants.

Walls occupy an important place in the content of building systems courses. Gypsum blocks and planks which are used in wall construction contain volatile gases such as xylene and toluene. Construction plaster contains ethylbenzene, formaldehyde and toluene while concrete and prefabricated buildings contain formaldehyde among volatile gases. ${ }^{18}$

Wallpapers which are taught in construction and materials courses contain toluene as well. Materials such as processed wood, wood-based plates, paint, varnish which are among interior surface coatings release ethylbenzene, tri-methylbenzene and xylene. ${ }^{19}$ These materials may cause eye and respiratory track irritation, headache, nausea and cancer. ${ }^{20}$ People exposed to low concentrations of these materials may suffer from neural system problems such as apathy, headache and tiredness; respiratory track diseases; and asthma. Most harmful volatile gases are benzene, toluene, ethylbenzene, xylene and styrene. ${ }^{21} \mathrm{High}$ concentrations of these gases have increased effects and they may cause coma and even death. ${ }^{22}$ Materials such as fiberglass and stone wool -among fibrous materialscontain asbestos ${ }^{23}$ and their effects may lead to lung cancer. $^{24}$

Content of the sanitation system courses generally focus on water chemistry and its effects on wet volumes. At this point, volatile gases in water -such as chlorine- may be released to the interior space. ${ }^{25}$ Suspended particles, bacteria, fungi and viruses may develop in wet spaces. ${ }^{26}$ Many new building materials may develop mold and bacteria in a few days. Mold may affect neural and immune systems. ${ }^{27}$ It may also

\footnotetext{
${ }^{18}$ Vaizoğlu et al., 2000, Vural and and Ünlü, 2013.

Balanlı, 2005 and Yildirim and ${ }^{23}$ Adıgüzel, 2011.

Ünlü, 2013.

19 Vural and Balanlı, 2005.

${ }^{20}$ Vaizoğlu et al., 2000.

${ }^{21}$ Lee et al., 2001.

Şenyiğit et al., 2004

${ }^{25}$ Vaizoğlu et al., 2000 and Yildirim and Ünlü, 2013.

${ }^{26}$ Vaizoğlu et al., 2000.

22 Sandmeyer, 1982 and Yildirim
}

cause allergic reactions and affect eye and upper respiratory system. Moisture control, cleaning and ventilation reduce the rate of these particles. ${ }^{28}$

Courses on heating, ventilation or titled as physical environment control are also included in the environmental systems course group therefore these courses are addressed in "Analysis of Courses on Environmental Systems" part of the study.

\section{Analysis of the Courses on Furniture, Equipment, Fixture and Material}

This group includes the courses on furniture design, furniture production, furniture material, equipment design, detail and modular system. Materials taught during these courses are explained below in the scope of their relation to indoor air pollutants.

Gas ranges and gas heaters; smoke released by wood and coal used in ovens and fireplaces; gas ranges, gas heaters and gas ovens and fireplaces are taught in the courses on equipment; fuel oil used for heating; and by cigarette smoke produce flammable gases. ${ }^{29}$ Smoke released by wood and coal used ovens and fireplaces in interior spaces produce carbon monoxide which may be deadly. ${ }^{30}$

Wood smoke contains some cancerogenics. Coal smoke contains high amounts of sulfur dioxide and comes down on cities as acid rain. Isolated primary and secondary fuel stoves are more environmental friendly and safe. ${ }^{31}$ People exposed to wood smoke may develop upper respiratory track irritation and chronic lung diseases. ${ }^{32}$ Carbon monoxide poisoning starts with unspecified symptoms such as dizziness, nausea and confusion and may be fatal in continued doses of poisoning..$^{33}$ It may cause headache, allergy and blackout and may result in cardiovascular system effects. ${ }^{34}$ Psychomotor system failures, deepening visual problems and central neural system effects may develop as well. ${ }^{35}$

Sulfur dioxide is a kind of gas produced during combustion of sulfur contained in solid and liquid fuels. High concentrations may cause eye irritation and cough, ${ }^{36}$ and by triggering upper and lower respiratory track diseases, result in asthma and lung infections particularly in children. ${ }^{37}$

\footnotetext{
${ }^{28}$ Vaizoğlu et al., 2000 and Yildirim ${ }^{33}$ Pearson, 1989 and Yıldırım, 2013. and Ünlü, 2013.

${ }^{29}$ Pearson, 1989 and Yildirim and 35 Tecer, 2011 and Yildirim and Ünlü, 2013.

30 Pearson 1989 Ünlü, 2013.

2000 and Yıldırım, 2013.

31 Pearson, 1989 and Yıldırım, 2013. ${ }^{37}$ Pearson, 1989, Yıldırım, 2013

32 Vaizoğlu vd., 2000.
} 
Nitrogen dioxide is released to interior space by gas ranges and heaters and increases the frequency of respiratory track diseases. ${ }^{38}$ Studies on houses heated by a stove and the houses where cigarette is smoked show that nitrogen dioxide released to the indoor environment affect lungs. ${ }^{39}$

Microwave, radio and television waves release radiation interior spaces that may damage cells and DNA. They may even lead to cancer. ${ }^{40}$

Varnishes taught in furniture, equipment and finishing materials courses contain volatile gases. ${ }^{41}$ These volatile gases are released to the indoor environment by wood and wood-based plates, paints, varnishes, glues and upholstery fabrics ${ }^{42}$ that contain formaldehyde. ${ }^{43}$ Release of high formaldehyde concentrations result in difficulty breathing by irritating skin, eyes, nose and throat and it may cause noise bleeding, nausea and tiredness. It is also known to have cancerogenic effects. ${ }^{44}$

Organochlorines one of the volatile gas groups related to the content of courses on furniture, equipment and finishing materials are poisonous and potentially cancerogenic and they react generally with the living fatty tissues creating life cycle. Organochlorines release harmful gases such as polyvinyl chloride (PVC) and more cancerogenic polychlorinated biphenyl (PCB). Soft plastics and polyvinyl chlorides may cause stillbirth, cancer, chronic bronchitis and skin diseases. Acrylics such as acrylonitrile-containing polyethylene are known to be cancerogenic. Polystyrene gases may irritate eyes, nose and throat and cause dizziness. In summary, different plastics release many fatal poisonous smoke and gases. ${ }^{45}$

Among all volatile gases, phenols are present in materials used in interior spaces such as polishers, detergents, garments and carpet cleaners, air cleaners, ammonia, turpentine, naphthalene, sodium hydroxide, acetone and chlorine. Harmful organic chemicals are released by the gas concentrations which are emitted to the indoor environment by materials such as paints; varnishes; paint removers, dissolvers, thinners; and glues when they dry. Metals contained in paints are quite harmful as well. These harmful gases which

\footnotetext{
38 Pearson, 1989 and Yıldırım, 2013.

2005, Lee et al.,2006 and Yildirim and Ünlü, 2013

${ }^{39}$ Güler ve Çobanoğlu, 1997 and ${ }^{43}$ Pearson, 1989 and Yıldırım, Yildirim and Ünlü, 2013. 2013

${ }^{40}$ Baker et al., 2008 and Yildirim ${ }^{44}$ Pearson, 1989, Vaizoğlu et al., and Ünlü, 2013.

${ }^{41}$ Vaizoğlu et al., 2000 and Yildirim and Ünlü, 2013 2000, Yıldırım, 2013 and Yildirim and Ünlü, 2013.

45 Pearson, 1989, Yıldırım, 2013,

42 Duygulu, 1996, Vural and Balanlı,
}

are released to the medium can easily penetrate into skin and lungs. These harmful gases are also dangerous for ozone layer as they release chlorofluorocarbon to the atmosphere. ${ }^{46}$ Volatile organic compounds and water-based acrylic latex paints (which no dot contain dissolvers) should be preferred against oil-based paints which are harmful for health. ${ }^{47}$

\section{Analysis of the Courses on Environmental Systems}

Courses on ecology, sustainability, landscape design, environmental design, urban design, heating and ventilation are analyzed in this group. Courses on heating and ventilation both are included in the interior architecture construction and building systems courses and the environmental systems courses. It is presented in Table 1 above that most of the courses offering information directly on human health are elective courses that only the heating and ventilation courses are compulsory. It is shown that the information on this issue is included in the content of compulsory courses as indirect information.

Concepts such as sustainability, energy saving and recycling as well as sensitivity about consumption of limited earth resources have turned into important parts of architectural production. ${ }^{48}$ Therefore, the same awareness is unavoidable for interior spaces as well. Polluted energy resources and unbalanced production-consumption relation have turned it into a more important task to ensure that indoor air is healthy enough to breath. For this reason, it is considerably significant to teach in the courses in environmental systems group the factors polluting not only the indoor but also the outdoor air and to address how the materials obtained from natural resources interact.

Flammable gases released by products such as natural gas, paraffin, oil, wood and coal produce carbon dioxide, carbon monoxide, sulfur dioxide and nitrogen dioxide and pollute the indoor and outdoor air by increasing global temperature. ${ }^{49}$ These gases cause headache, loss of appetite, nose, eye and throat irritation and irritation of upper respiratory track..$^{50}$

Exhaust gases emitted by motor vehicles and industrial activities release nitrous oxides and volatile organic compounds to the atmosphere. These compounds react with sunlight and produce ozone and

\footnotetext{
${ }^{46}$ Pearson, 1989, Yıldırım, $2013{ }^{49}$ Pearson, 1989 and Yildirim and and Yildirim and Ünlü, 2013.

47 Altun, 2007

48 Altun, 2007
} 
photochemical products. ${ }^{51}$ Some fuels used in indoor heaters and electrical appliances such as printer, photocopy machine and computer can produce ozone. Ozone may cause respiratory problems and serious asthma in children, the old, and the people with respiratory diseases and even in healthy people when inhaled at high concentrations. ${ }^{52}$ Throat irritation, cough, chest pain and inflammation in inner surfaces of lung may be possible results of ozone inhalation. ${ }^{53}$

Among the harmful gases, radon is related to geographical conditions of the region and has differing levels of effect depending on the building materials and insulation. ${ }^{54}$ It is a heavy polluter produced by uranium degradation under normal conditions; by construction materials such as granite and lime stone; or diffused into air by well water from the lower surfaces of the earth. Radon gas present in the soil extracted from underground; bricks and natural stones produced from raw materials obtained from underground; building materials and elements containing natural stone; ${ }^{55}$ and some granites with low sandstone content ${ }^{56}$ cause lung cancer. ${ }^{57}$ Indoor ventilation helps reducing the effects of these incidences. It is of significant importance to include this subject in the courses on climatization.

Conditions enabling climatization can be produced naturally or mechanically that air conditions are one of the mechanical ways. Legionnaires' disease develops as a result of mixing with airflow of the microorganisms developing in the pool of the air moisturizer of the air conditioning plant and it poses fatal threat. Legionnaires' disease draws a table similar to a chest disease like pneumonia; it starts with high temperature, sweating, heavy headache and muscle pain and it develops into a fatal disease with dry cough, shortness of breath and diarrhea. Production of air conditioning system equipment in such way to prevent virus, bacteria and fungi development and periodical cleaning and maintenance of these elements may be a solution for the related health problems. Laminar flow hygienic conditioning systems should be preferred particularly for hospitals and operation rooms. ${ }^{58}$

\section{Analysis of the Courses on Regulations and Directives}

This group includes courses on building management, building cost, laws, regulations, directives and

\footnotetext{
51 Tecer, 2011.

52 Yurtseven, 2007 and Yıldırım, 2013.

${ }^{55}$ Yurtseven, 2007 and Yıldırım, 2013.

${ }^{56}$ Adıgüzel, 2011.

${ }^{53}$ Tecer, 2011 and Yildirim and ${ }^{57}$ Yurtseven, 2007, Yıldırım, 2013 Ünlü, 2013.

${ }^{54}$ Vaizoğlu et al., 2000.
}

standards. Information on sustainability rules, sectoral rules, fire and accessibility should also be included in these courses.

Materials to be used in interior equipment elements by both producers and consumers shall comply with particularly E1 and B1 norms of the European Union Quality Standards. E1 norm is related to gas emission from interior equipment elements into the medium while B1 norm is related to flammability level of these elements. These two norms are quite important in deciding on reliability for public health of the materials to be preferred in design of interior equipment elements. ${ }^{59}$ In Turkey, building materials standards are detected, new standards are developed and all standards are controlled by the Turkish Standards Institution (TSE). However, material standardization remains at low levels and controls on standardized material production tent to fail. ${ }^{60}$

Communiqué on Assignment and Control of Institutions Approved as per Construction Products Regulation (305/2011/EU) issued in the Official Gazette dated 18.08.2013 and No 28739 defines the basic qualifications and rules of building materials. This communiqué presents items on poisonous gas emission; volatile organic compounds; dangerous radiation; dangerous leakages to underground water and sea water, ground water and soil and drinking water; waste water discharge; emission of chimney gases; and humid-free interior surfaces. ${ }^{61}$

\section{Research Method}

\section{Research Universe and Participants}

Research universe of the present study was defined as Interior Architecture and Environmental Design Department of Atılım, Hacettepe and Selçuk Universities. Among all $4^{\text {th }}$ grade students of these departments, 95 students were included in the study as study participants: $23 \%$ of these graduation candidates (22 students) were attending at Hacettepe University, 33\% (31 students) at Selçuk University and 44\% (42 students) at Atlım University.

\section{Design and Administration of Questionnaire}

Questionnaires which were found to be reliable and valid in previous similar studies ${ }^{62}$ were taken into consideration to develop a detailed questionnaire while designing study. Developed questionnaire was used to test study hypothesis. Closed-end question, multiple

\footnotetext{
59 Yildirim and Ünlü, 2013.

${ }^{60}$ Aykanat, 2014.

${ }^{61}$ Aykanat, 2014
}

62 Yildirim et al., 2011, Yildirim et
al., 2012 and Yildirim and Ünlü, 2013. 
choice question and multi-option question techniques were used in this questionnaire. To measure knowledge level of the respondents, 11 questions were asked in the first part and 6 questions were asked in the second part of the questionnaire. It was administered according to face-to-face interview method in order to measure knowledge level of participants regarding harmful effects on human health of the pollutants released to the medium by the interior equipment elements. It was administered to potential graduates of all three universities simultaneously in the last week of 2013 Spring Semester (at the end of May). Participants responded to the questionnaire approximately in 20 minutes. Statistical analyses of the each questionnaire item are presented below.

\section{Statistical Analyses}

In the scope of this study, "dependent variable" was detected as participant evaluations about their knowledge level about the effects on human health of the pollutants released by the interior equipment elements. There are many factors effective on participant evaluations. Among these factors, "university attended" is defined as "independent variable". To test study hypothesis, Cronbach Alpha reliability coefficients, mean and standard deviation scores were calculated for the obtained data. Then, Chi-Square test was made to detect the relationship between the dependent and independent variables related to detection of evaluations made to reveal the knowledge level about harmful effects on human health of the pollutants released by interior equipment elements. One-way variance analysis (ANOVA) was made to set the statistical significant of the differences between the dependent variable (based on participant evaluations) and independent variable. SPSS (Statistical Package for the So-

Table 2. Reliability analysis of dependent variables

Dependent variables

$\begin{array}{cc}\text { Item } & \text { Scale } \\ \text { reliability } & \text { reliability }\end{array}$

0.850

0.848

0.848

0.841

0.846

0.854

0.859

0.859

0.840

0.839

0.803 of soil, brick and natural stone cause lung cancer.

teratogens, viruses and bacteria which cause serious health problems and allergenics;

I know flammable, volatile and harmful gases and particles and radiation.

A10 I have knowledge of the scope of Norm E1 of the European Quality Standards.

I have knowledge of the scope of Norm B1 of the European Quality Standards.

0.722

0.725

Which of the materials released by interior equipment elements are harmful for health?

0.708

0.724 by the gases released to the medium by artificial materials such as particle boards, fiberboards, laminated and PVC?

B4 Which pollutants result in indoor air pollution? 
Table 3. Mean, standard deviation and homogeneity group values of the dependent variables

\begin{tabular}{|c|c|c|c|c|c|c|c|c|c|c|c|}
\hline \multirow[t]{3}{*}{ Dependent variables } & \multicolumn{9}{|c|}{ University } & & \\
\hline & \multicolumn{3}{|c|}{ Atılım } & \multicolumn{3}{|c|}{ Hacettepe } & \multicolumn{3}{|c|}{ Selçuk } & \multicolumn{2}{|c|}{ Total } \\
\hline & M & SD & HG & M & SD & HG & $\mathbf{M}$ & SD & HG & M & SD \\
\hline A1 & $3.52^{\mathrm{a}}$ & 0.89 & B & 3.59 & 0.73 & B & 2.96 & 0.87 & A & 3.35 & 0.88 \\
\hline A2 & 3.02 & 0.64 & B & 3.00 & 0.69 & B & 3.48 & 0.72 & A & 2.84 & 0.71 \\
\hline A3 & 3.02 & 0.99 & A & 2.90 & 1.06 & A & 2.74 & 0.89 & A & 2.90 & 0.97 \\
\hline A4 & 2.78 & 1.17 & A & 2.72 & 1.07 & A & 2.54 & 1.23 & A & 2.69 & 1.16 \\
\hline A5 & 3.14 & 1.15 & A & 2.50 & 1.18 & A & 2.51 & 1.06 & A & 2.78 & 1.16 \\
\hline A6 & 3.04 & 1.20 & A & 2.95 & 1.55 & A & 3.03 & 1.12 & A & 3.02 & 1.26 \\
\hline A7 & 1.90 & 0.82 & A & 1.81 & 0.79 & A & 2.13 & 0.93 & A & 1.96 & 0.85 \\
\hline A8 & 3.54 & 1.10 & B & 3.86 & 0.99 & B & 2.74 & 1.18 & A & 3.35 & 1.18 \\
\hline A9 & 3.23 & 1.07 & $A B$ & 3.45 & 1.10 & B & 2.61 & 0.91 & A & 3.08 & 1.07 \\
\hline A10 & 4.40 & 0.88 & B & 4.68 & 0.64 & B & 3.64 & 1.17 & A & 4.22 & 1.02 \\
\hline A11 & 4.38 & 0.96 & B & 4.81 & 0.50 & B & 3.67 & 1.01 & A & 4.25 & 0.98 \\
\hline
\end{tabular}

M: Mean value; SD: Standard deviation; HG: Homogeneity Group.

aean value of the variables listed in 1-5 (big figures represent negative answers).

cial Sciences) Statistical Package Program was used for data analysis.

\section{Findings}

Cronbach Alpha test was used to test reliability of the dependent variables including evaluations of graduation candidates on their level of knowledge about the effects on human health of the pollutants released by interior equipment elements. Results are presented in Table 2. Accordingly, reliability coefficient of the study questionnaire (composed of two different groups of items: 11-item, part one and 6-item, part two) measuring knowledge of interior architect candidates was found to be 0.803 . In addition, reliability coefficient was calculated to be 0.859 for the first group knowledge items and to be 0.724 for the second group knowledge items. Previous studies by Bagozzi \& $\mathrm{Yi}^{63}$ McKinley et al., ${ }^{64}$ Bosma et al.,, ${ }^{65}$ Apaydın et al., ${ }^{66}$ and Karasar $^{67}$ reported that alpha reliability coefficient would be deemed "reliable" if above 0.60 . Cronbach Alpha coefficient of the present study is recorded to be above this value. Accordingly, questionnaire used in the present study can be deemed "reliable".

Table 3 presents mean, standard deviation and homogeneity group values of the knowledge of the graduation candidates about the pollutants released to the medium by the interior equipment elements.

\footnotetext{
${ }^{63}$ Bogazzi and Yi, 1988.

${ }^{64}$ McKinley et al., 1997

${ }^{65}$ Bosma et al., 1997.
}

${ }^{66}$ Apaydın et al., 1994.
Examination of the mean values presented in Table 3 shows differences between the evaluations made by graduation candidates about their knowledge of the pollutants released by interior equipment materials to the medium. Graphical representation of the differences between evaluations made by the graduation candidates is shown in Figure 1.

Figure 1 shows that evaluations made by graduation candidates of three different universities about the harmful effects on human health of the pollutants released to the medium by the interior equipment elements (which are addressed by 11 items) are generally parallel; however, there are university-based differences between the level of knowledge of the graduation candidates about the items A1, A2, A5, A8, A9, $A 10$ and $A 11$. Accordingly, ANOVA test was made to detect the degree of the university-based difference between the knowledge levels of the graduation candidates about the effects on human health of the pollutants released by the interior equipment elements to the medium. Results of the ANOVA test showed a statistically significant difference $(p<0.05)$ between the evaluations of the graduation candidates of each three universities for the items $A 1(F=4.871 ; d f=2 ; p=0.010)$, A2 $(F=6.368 ; d f=2 ; p=0.003), \quad A 5 \quad(F=3.654 ; d f=2$; $p=0.030), A 8(F=7.699 ; d f=2 ; p=0.001), A 9(F=5.093$; $d f=2 ; p=0.008), A 10(F=9.184 ; d f=2 ; p=0.000)$ and A11 ( $F=11.187 ; d f=2 ; p=0.000)$. On the other hand, no such statistically significant difference $(p<0.05)$ was found for the items $A 3(F=0.735 ; d f=2 ; p=0.482), A 4$ $(F=0.375 ; d f=2 ; p=0.689), A 6(F=0.040 ; d f=2 ; p=0.960)$ 


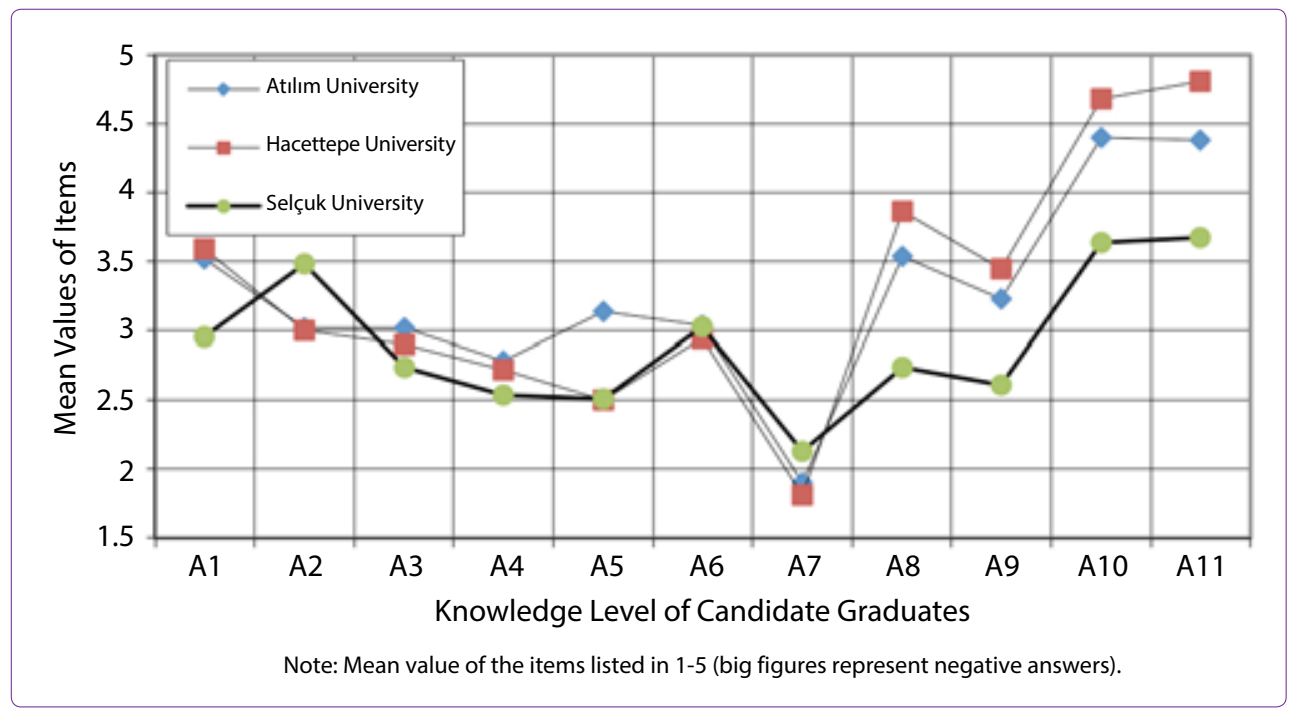

Figure 1. Evaluations made by graduation candidates about indoor air pollutants.

and $A 7(F=1.248 ; d f=2 ; p=0.292)$. In conclusion, these university-based differences may have resulted from the difference in the rates of inclusion of the information on the pollutants released to the medium by the interior equipment elements in the curriculum of the three study universities.

In this part of the study, results of the measurement of the level of knowledge of the graduation candidates about the effects on human health of the pollutants released to the medium by the interior equipment elements as well as the results related to the differences between the university groups are presented respectively. Firstly, knowledge level of the graduation candidates about indoor release of harmful chemicals was detected. Table 4 presents these detections.

According to Table 4, $77.9 \%$ of the graduation candidates know that glues used in interior equipment materials, 22.1\% know that carpets and garments, 91.6\% know that paints and varnishes, $25.3 \%$ know that particle boards and $38.9 \%$ know that ceiling, wall and floor coverings contain harmful chemicals. It can be concluded from these results that a significant part of the graduation candidates are aware of the harmful chemicals contained by paints, varnishes and glues while there is insufficient knowledge among graduation candidates on harmful chemicals contained by carpets, garments and particle plates. Moreover, results of Chi-Square tests did not reveal a university-based statistically significant difference $(p<0.05)$ between the evaluations of the graduation candidates except for the results related to particle plate. In conclusion, graduation candidates of Selçuk University were recorded to have lower knowledge than those of the other universities on the harmful chemicals contained by particle plate.

Table 4. Indoor harmful chemical release resources (B1)

\begin{tabular}{|c|c|c|c|c|c|c|c|c|c|}
\hline \multirow[t]{3}{*}{ Dependent variables } & \multicolumn{6}{|c|}{ University } & & & \\
\hline & \multicolumn{2}{|c|}{ Atılım } & \multicolumn{2}{|c|}{ Hacettepe } & \multicolumn{2}{|c|}{ Selçuk } & \multicolumn{3}{|c|}{ Result } \\
\hline & $\mathbf{F}$ & $\%$ & $\mathbf{F}$ & $\%$ & $\mathbf{F}$ & $\%$ & $\mathbf{X}^{2}$ & df & $\mathbf{P}^{*}$ \\
\hline Glues & 35 & 36.8 & 18 & 18.9 & 21 & 22.1 & 2.774 & 2 & 0.250 \\
\hline Carpets and garments & 8 & 8.4 & 8 & 8.4 & 5 & 5.3 & 3.469 & 2 & 0.177 \\
\hline Paints and varnishes & 40 & 42.1 & 18 & 18.9 & 29 & 30.5 & 3.603 & 2 & 0.165 \\
\hline Particle plates & 11 & 11.6 & 10 & 10.5 & 3 & 3.2 & 8.758 & 2 & $0.013^{*}$ \\
\hline Ceiling, wall and floor coverings & 20 & 21.1 & 8 & 8.4 & 9 & 9.5 & 2.672 & 2 & 0.263 \\
\hline
\end{tabular}

F: Number of Samples; \%: Value in Percentage; $X^{2}$ : Chi-Square; df: Degree of Freedom. ${ }^{*} p<0.05$ Level of Statistical Significance. 
Table 5 shows the knowledge level of the graduation candidates related to volatile organic compounds released to the medium by interior equipment elements and harmful to health.

According to Table 5, 75.8\% of the graduation candidates know that formaldehyde, 31.6\% know that benzene, $18.9 \%$ know that trichloroethylene, $15.8 \%$ know that xylene/toluene and $36.8 \%$ know that ammonia -which are contained by the interior equipment elements- are harmful to human health. It can be concluded from these results that a significant part of graduation candidates know that formaldehyde is harmful to human health while there is insufficient knowledge among candidates on benzene, trichloroethylene, xylene/toluene and ammonia. Moreover, results of Chi-Square tests did not reveal a university-based statistically significant difference $(p<0.05)$ between the evaluations of the graduation candidates except for the results related to formaldehyde. In conclusion, graduation candidates of Selçuk University were recorded to have higher knowledge than the other candidates from the selected universities on the harmful effects of formaldehyde.

According to Table $6,41.1 \%$ of the graduation candidates know that air polluted by the gases released to the medium by the artificial materials such as particle plate, fiberplate, laminate and PVC cause eye irritation, $63.2 \%$ know that it causes throat irritation, $26.3 \%$ know that it causes skin rash, $60 \%$ know that it causes headache and $68.4 \%$ know that it causes difficulty of breathing. It can be concluded from these results that a significant part of the graduation candidates know that organic chemicals released to the medium by materials result in throat irritation, headache and difficulty of breathing while there is insufficient knowledge among them that they may also cause skin rash. Moreover, results of Chi-Square tests did not reveal a university-based statistically significant difference $(p<0.05)$ between the evaluations of the graduation candidates.

Table 7 presents the knowledge level of the graduation candidates on pollutants causing indoor air pollution.

Table 5. Volatile organic compounds released to the medium by the interior equipment elements (B2)

\begin{tabular}{|c|c|c|c|c|c|c|c|c|c|}
\hline \multirow[t]{3}{*}{ Dependent variables } & \multicolumn{6}{|c|}{ University } & & & \\
\hline & \multicolumn{2}{|c|}{ Atılım } & \multicolumn{2}{|c|}{ Hacettepe } & \multicolumn{2}{|c|}{ Selçuk } & \multicolumn{3}{|c|}{ Result } \\
\hline & $\mathbf{F}$ & $\%$ & $\mathbf{F}$ & $\%$ & $\mathbf{F}$ & $\%$ & $\mathbf{X}^{2}$ & df & $\mathbf{P}^{*}$ \\
\hline Formaldehyde & 35 & 36.8 & 20 & 21.1 & 17 & 17.9 & 11.459 & 2 & $0.003^{*}$ \\
\hline Benzene & 16 & 16.8 & 4 & 4.2 & 10 & 10.5 & 2.660 & 2 & 0.265 \\
\hline Trichloroethylene (TCE) & 10 & 10.5 & 1 & 1.1 & 7 & 7.4 & 3.884 & 2 & 0.143 \\
\hline Xylene/Toluene & 9 & 9.5 & 1 & 1.1 & 5 & 5.3 & 3.099 & 2 & 0.212 \\
\hline Ammonia & 17 & 17.9 & 6 & 6.3 & 12 & 12.6 & 1.151 & 2 & 0.563 \\
\hline
\end{tabular}

F: Number of Samples; \%: Values in Percentage; $X^{2}$ : Chi-Square; df: Degree of Freedom.

${ }^{*} p<0.05$ Level of Statistical Significance.

Table 6. Symptoms observed in people exposed to air polluted by volatile gases (B3)

\begin{tabular}{|c|c|c|c|c|c|c|c|c|c|}
\hline \multirow[t]{3}{*}{ Dependent variables } & \multicolumn{6}{|c|}{ University } & & & \\
\hline & \multicolumn{2}{|c|}{ Atılım } & \multicolumn{2}{|c|}{ Hacettepe } & \multicolumn{2}{|c|}{ Selçuk } & \multicolumn{3}{|c|}{ Result } \\
\hline & $\mathbf{F}$ & $\%$ & $\mathbf{F}$ & $\%$ & $\mathbf{F}$ & $\%$ & $\mathbf{X}^{2}$ & df & $\mathbf{P}^{*}$ \\
\hline Eye irritation & 15 & 15.8 & 8 & 8.4 & 16 & 16.8 & 2.123 & 2 & 0.346 \\
\hline Throat irritation & 29 & 30.5 & 13 & 13.7 & 18 & 18.9 & 1.128 & 2 & 0.569 \\
\hline Skin rash & 9 & 9.5 & 6 & 6.3 & 10 & 10.5 & 1.092 & 2 & 0.579 \\
\hline Headache & 27 & 28.4 & 12 & 12.6 & 18 & 18.9 & 0.643 & 2 & 0.725 \\
\hline Difficulty of breathing & 30 & 31.6 & 16 & 16.8 & 19 & 20.0 & 1.094 & 2 & 0.579 \\
\hline
\end{tabular}

F: Number of Samples; \%: Values in Percentage; $X^{2}$ : Chi-Square; df: Degree of Freedom.

${ }^{*} \mathrm{p}<0.05$ Level of Statistical Significance. 
Table 7. Pollutants causing indoor air pollution (B4)

\begin{tabular}{|c|c|c|c|c|c|c|c|c|c|}
\hline \multirow[t]{3}{*}{ Dependent variables } & \multicolumn{6}{|c|}{ University } & & & \\
\hline & \multicolumn{2}{|c|}{ Atılım } & \multicolumn{2}{|c|}{ Hacettepe } & \multicolumn{2}{|c|}{ Selçuk } & \multicolumn{3}{|c|}{ Result } \\
\hline & $\mathbf{F}$ & $\%$ & $\mathbf{F}$ & $\%$ & $\mathbf{F}$ & $\%$ & $\mathbf{x}^{2}$ & df & $\mathbf{P}^{*}$ \\
\hline Nitrogen dioxide & 12 & 12.6 & 1 & 1.1 & 11 & 11.6 & 6.960 & 2 & $0.031^{*}$ \\
\hline Carbon monoxide & 33 & 34.7 & 15 & 15.8 & 19 & 20.0 & 2.638 & 2 & 0.267 \\
\hline Formaldehyde & 28 & 29.5 & 14 & 14.7 & 18 & 18.9 & 0.570 & 2 & 0.752 \\
\hline Ozone & 12 & 12.6 & 3 & 3.2 & 8 & 8.4 & 1.819 & 2 & 0.403 \\
\hline Asbestos & 14 & 14.7 & 2 & 2.1 & 6 & 6.3 & 5.142 & 2 & 0.076 \\
\hline
\end{tabular}

F: Number of Samples; \%: Values in Percentage; $X^{2}$ : Chi-Square; df: Degree of Freedom.

${ }^{*} \mathrm{p}<0.05$ Level of Statistical Significance.

Table 8. Gases released by paints and varnishes (B5)

\begin{tabular}{|c|c|c|c|c|c|c|c|c|c|}
\hline \multirow[t]{3}{*}{ Dependent variables } & \multicolumn{6}{|c|}{ University } & & & \\
\hline & \multicolumn{2}{|c|}{ Atılım } & \multicolumn{2}{|c|}{ Hacettepe } & \multicolumn{2}{|c|}{ Selçuk } & \multicolumn{3}{|c|}{ Result } \\
\hline & $\mathbf{F}$ & $\%$ & $\mathbf{F}$ & $\%$ & $\mathbf{F}$ & $\%$ & $\mathbf{X}^{2}$ & df & $\mathbf{P}^{*}$ \\
\hline Formaldehyde & 24 & 25.3 & 17 & 17.9 & 20 & 21.1 & 2.548 & 2 & 0.280 \\
\hline Xylene/Toluene & 16 & 16.8 & 3 & 3.2 & 10 & 10.5 & 4.138 & 2 & 0.126 \\
\hline Benzene & 17 & 17.9 & 6 & 6.3 & 12 & 12.6 & 1.151 & 2 & 0.563 \\
\hline Alcohol & 3 & 3.2 & 2 & 2.1 & 7 & 7.4 & 4.177 & 2 & 0.124 \\
\hline Trichloroethylene (TCE) & 13 & 13.7 & 2 & 2.1 & 8 & 8.4 & 3.824 & 2 & 0.148 \\
\hline
\end{tabular}

F: Number of Samples; \%: Values in Percentage; $X^{2}$ : Chi-Square; df: Degree of Freedom.

${ }^{*} \mathrm{p}<0.05$ Level of Statistical Significance.

Table 7 shows that $25.3 \%$ of the graduation candidates have knowledge of nitrogen dioxide, $70.5 \%$ know carbon monoxide, $63.2 \%$ know formaldehyde, $24.2 \%$ know ozone and $23.2 \%$ know asbestos as the pollutants causing indoor air pollution. Accordingly, a significant part of the graduation candidates has knowledge of carbon monoxide and formaldehyde but there is insufficient knowledge among them on about nitrogen dioxide, ozone and asbestos among the pollutants causing indoor air pollution. Moreover, results of Chi-Square tests did not reveal a university-based statistically significant difference $(p<0.05)$ between the evaluations of the graduation candidates except for the results related to nitrogen dioxide. In conclusion, candidates of Hacettepe University were recorded to have lower knowledge than those of the other universities on nitrogen dioxide.

Knowledge level of the graduation candidates regarding gases released by paints and varnishes used in interior environments is shown in Table 8.

According to Table $8,64.2 \%$ of the graduation can- didates have knowledge of formaldehyde, $30.5 \%$ know xylene/toluene, $36.8 \%$ know benzene and $12.6 \%$ know alcohol as the gases released by paints and varnishes used in interior environments. It is also seen that $24.2 \%$ of the graduation candidates ticked trichloroethylene although this gas was not in this group. It can be concluded from these results that a significant part of the graduation candidates are aware of formaldehyde as a gas released by paints and varnishes while there is insufficient knowledge among them about xylene/toluene, benzene and alcohol. In addition, results of Chi-Square tests did not reveal a university-based statistically significant difference $(p<0.05)$ between the evaluations of the candidates on.

Table 9 presents the knowledge level of the graduation candidates regarding the materials containing formaldehyde and used as glue and preservative material in the interior equipment elements and accessories.

Table 9 reveals that $77.9 \%$ of the graduation candidates know that formaldehyde which is used as varnish and preservative material in interior equipment ele- 
Table 9. Interior equipment element materials containing formaldehyde (B6)

\begin{tabular}{|c|c|c|c|c|c|c|c|c|c|}
\hline \multirow[t]{3}{*}{ Dependent variables } & \multicolumn{6}{|c|}{ University } & & & \\
\hline & \multicolumn{2}{|c|}{ Atılım } & \multicolumn{2}{|c|}{ Hacettepe } & \multicolumn{2}{|c|}{ Selçuk } & \multicolumn{3}{|c|}{ Result } \\
\hline & $\mathbf{F}$ & $\%$ & $\mathbf{F}$ & $\%$ & $\mathbf{F}$ & $\%$ & $\mathbf{X}^{2}$ & df & $\mathbf{P}^{*}$ \\
\hline Particle plates & 34 & 35.8 & 17 & 17.9 & 23 & 24.2 & 0.480 & 2 & 0.787 \\
\hline Fiberplates & 24 & 25.3 & 15 & 15.8 & 14 & 14.7 & 2.821 & 2 & 0.244 \\
\hline Plywood & 29 & 30.5 & 13 & 13.7 & 21 & 22.1 & 0.683 & 2 & 0.711 \\
\hline Upholstery fabrics & 15 & 15.8 & 6 & 6.3 & 10 & 10.5 & 0.471 & 2 & 0.790 \\
\hline Carpets & 11 & 11.6 & 5 & 5.3 & 5 & 5.3 & 1.055 & 2 & 0.590 \\
\hline
\end{tabular}

F: Number of Samples; \%: Values in Percentage; $X^{2}$ : Chi-Square; df: Degree of Freedom.

${ }^{*} p<0.05$ Level of Statistical Significance.

ments and accessories are present in particle plates, $55.8 \%$ know that it is present in fibrillates, $66.3 \%$ know that it is present in plywood, $32.6 \%$ know that it is present in upholstery fabrics and $22.1 \%$ know that it is present in carpets. Accordingly, it is understood that a significant part of the graduation candidates are aware of formaldehyde content of wood-based plates while there is insufficient knowledge among them on formaldehyde content of upholstery fabrics and carpets. Moreover, results of Chi-Square tests did not reveal a university-based statistically significant difference $(p<0.05)$ between the evaluations of the graduation candidates.

\section{Conclusion and Suggestions}

General evaluation of the study results show that graduation candidates of the Interior Architecture and Environmental Design Department of the three universities included in the study scope have low level of knowledge regarding the harmful effects of the pollutants released to the medium by interior equipment elements. It is quite important for human health to increase the number of compulsory courses and course contents offering indoor air pollutants for the students attending at Interior Architecture and Environmental Design Departments with the general aim of providing interior architect candidates with sufficient knowledge on indoor air pollutants. By this way, such improvement in curriculum will increase knowledge level of the interior designers regarding harmful effects of indoor air pollutants on human health. When these candidates will take their place in the industry and at different decision-making levels, community health will also be protected and such knowledge will be transferred to the users.

Moreover, most of the interior architect candidates are observed to be aware of the harmful chemicals contained by paints and varnishes while they are also recorded to have insufficient knowledge on the harmful chemicals contained by carpets, garments and plates. These results point the necessity of increasing textile and wood-based plate content of the courses included in the course group of furniture, equipment, fixture, finishing material, interior architecture construction and building systems. Meanwhile, formaldehyde is recorded to be known by a significant part of the interior architect candidates to be harmful to human health; however, these candidates are seen to have insufficient knowledge of benzene, trichloroethylene, xylene/toluene and ammonia. This knowledge gap can be filled by increasing the volatile gas content of the courses particularly in the course group of material, interior architecture construction and building systems. Moreover, lower level of knowledge on pollutants such as nitrogen dioxide can be increased by updating content of courses on furniture and by turning elective courses in environmental systems group into compulsory courses or through inclusion of ecology and sustainability courses in the curriculum.

In addition, while around 60\% interior architect candidates of the study universities are aware of the harmful effects of the air polluted by the gasses (released to the air by artificial materials such as particle plates, fiberplates, laminates and PVC) such as throat irritation, headache and difficulty of breathing; however, knowledge among them about eye and skin irritation caused by these gases seems to remain insufficient. Accordingly, it would be useful to update the content of the course group of interior architecture construction and building systems, to closely monitor new studies on these subjects and to take support of the experts of the related disciplines when necessary. On the other hand, carbon monoxide and formaldehyde among pollutants are observed to be known by 
the graduation candidates; however, nitrogen dioxide, ozone and asbestos are recorded to be unknown by the majority. In this scope, course contents of the course group of interior architecture construction and building systems and the course group of environmental design should be re-organized in all three universities from the aspect of human health and indoor air pollutants. These courses most of which are offered as elective courses in the studied universities should be made compulsory, which will enable graduation of students with higher level of knowledge.

In conclusion, increasing the amount of information offered in curriculum in relation to interaction between building product and environment in life cycle processes will not only assist the designer in making right decisions on building products, in guiding building product manufacturers and in playing determinant role -as one of the decision-makers- in preparation and enforcement of laws and regulations but also contribute to awareness-raising among users and development of new production technologies. To this end, instructors offering courses in Interior Architecture and Environmental Design Departments should establish contact with other disciplines with the help of scientific and technological developments. Therefore, new knowledge to be acquired should be reflected to the education of candidate designers to ensure turning of the concepts of sustainability and environmentalism into a habit through life-long learning, to promote environmental-friendly usages and to increase the number of training programs to be organized in cooperation with users.

In general, weight and content of the compulsory and elective environmental systems courses taught in the studied universities is revealed to be quite limited. According to course analyses and questionnaire results, in order for new designers to develop universal quality and value standards, they should be equipped with the knowledge of materials with no harmful effect on human health. Learning outputs of the curriculum should be reconsidered and developed. Interdisciplinary support and relations should be established. In addition, it seems quite important for the lecturers teaching these subjects to update their knowledge.

Since curriculum are observed to be composed heavily of elective courses, students should be supported to take elective courses on environmental systems which cannot be turned into compulsory courses in the short term. Support should be given for writing of new environmental systems course books and translation of foreign ones into Turkish.
Standards issued by international organizations such as CIDA and Bologna process standards need to be implemented sensitively in the curriculum of the Interior Architecture and Environmental Design Departments in Turkey.

Ministry of Health, Higher Education Council and Chamber of Interior Architects should produce projects in cooperation with universities in relation to the curriculum of Interior Architecture and Environmental Design Departments. To raise awareness among students attending at the Interior Architecture and Environmental Design Departments, these students should be made visit related departments of hospitals to get information.

Previous studies on curriculum should be utilized in the context of environmental systems and new studies should be made on optimal course methods and processes.

\section{Acknowledgements}

The authors would like to express their sincere thanks to Assoc. Prof. Dr. M. Lütfi HIDAYETOĞLU in Selçuk University and Instructor Dr. Ayşen ÇAPANOĞLU in Hacettepe University for their great contributions in acquisition process of the present study.

\section{References}

Adıgüzel, D. (2011) Türkiye'deki iç Mimarlık Eğitiminde Çevresel Yaklaşım, Master Thesis, İstanbul, Kadir Has Üniversitesi, Sosyal Bilimler Enstitüsü.

Altun, D.A. (2007) “Geleceğin Mimarlığı: Bilimsel-Teknolojik Değişimlerin Mimarlığa Etkileri", DEÜ Mühendislik Fakültesi Fen ve Mühendislik Dergisi, Vol. 9: 1, pp. 77-91.

Apaydın, A., Kutsal, A. and Atakan, C. (1994) Uygulamalı İstatistik, Ankara, Baran Ofset.

Aykanat, A. (2014) "Yapı Hasarları Açısından Doğru Malzeme Seçimini Sağlayan Kuramsal Tasarım ve Yapım Modeli", Artium, Vol. 2: 1, pp. 29-42.

Bagozzi, R.P. and Yi, Y. (1988) “On the Evaluation of Structural Equation Models", Journal of the Academy of Marketing Science Spring, Vol.16: 1, pp. 74-94.

Baker-Laporte, P., Elliot, E. and Banta, J. (2008) Prescriptions for a Healty House: A Practical Guide for Architects, Builders and Homeowners, Beverly Hills, Pomegranate Press.

Bosma, H., Marmot, M.G., Hemingway, H., Nicholson, A.C., Brunner, E. and Stansfield, S.A. (1997) "Low Job Control and Risk of Coronary Heart Disease in Whitehall II (Prospective Cohort) Study", British Medical Journal, Vol. 314: 7080, pp. 558-565.

Brunekreef, B. and Holgate, S.T. (2002) "Air Pollution and Health", The Lancet, Vol. 360: 19, pp. 1233-1242.

Chang, C.C., Ruhl, R.A., Halpern, G.M. and Gershwin, M.E. (1993) "The Sick Building Syndrome. I. Definition and Epidemiological Considerations", Journal of Asthma, Vol. 
30: 4, pp. 285-295.

Çimen, M. and Öztürk, S. (2010) "Küresel Isınma, İklim Değişikliğinin Solunum Sistemi Üzerine Etkisi ve Büyükşehir Bronşiti", Fırat Üniversitesi Sağlık Bilimleri Tıp Dergisi, Vol. 24: 2, pp. 141-146.

Çobanoğlu, N. and Kiper, N. (2006) "Bina İçi Solunan Havada Tehlikeler", Çocuk Sağlığı ve Hastalıkları Dergisi, Vol. 49: 1, pp. 71-75.

Duygulu, i. (1996) “iç Mekânlarda Yapı Malzemelerine Bağlı Hava Kirliliği", Mimarlık, No. 269, pp. 39-41.

EPA. (2004) "Air Quality Criteria for Particulate Matter", Washington, US Environmental Protection Agency, EPA/600/P-99/002bF.

Gökbel, H. and Uzun, K. (1995) "Hava Kirliliğinin Solunum Fonksiyonlarına Etkisi", Ekoloji Çevre Dergisi, No. 15, pp. 4-5.

Güler, Ç. and Çobanoğlu, Z. (1997) Kimyasallar ve Çevre, Ankara, Sağlık Bakanlığı.

Johnson, B.R. and Hill, K. (2002) Ecology and Design: Frameworks for Learning, Washington DC, Island Press.

Jones, A.P. (1999) "Indoor Air Quality and Health", Atmospheric Environment, Vol. 33: 28, pp. 4535-4564.

Karasar, N. (1995) Bilimsel Araştırma Yöntemi, Ankara, 3A Araştırma Eğitim Danışmanlık Ltd. Şti.

Köksal, Y. (2001) "Kapalı Mahallerde Hava Kalitesinin İyileştirilmesi", V. Ulusal Tesisat Mühendisliği Kongresi ve Sergisi, 3-6 October 2001, İzmir, TMMOB Makine Mühendisleri Odası İzmir Şubesi, pp. 625-645.

Krzyzanowski, M. and Cohen, A. (2008) "Update of WHO air quality guidelines", Air Qual Atmos Health, Vol.1, pp. 7-13.

Lee, C., Dai, Y., Chien, C. and Hsu, D. (2006) "Characteristics and Health Impacts of Volatile Organic Compounds in Photocopy Centers", Environmental Research, Vol. 100: 2, pp.139-149.

Lee, S., Lam, S. and Fai, H. (2001) "Characterization of VOCs, Ozone, and PM10 Emissions from Office Equipment in an Environmental Chamber", Building and Environment, Vol. 36: 7, pp. 837-842.

Levins, H. (1996) "Best Sustainable Indoor Air Quality Practices in Commercial Buildings in Environmental Building News", Third Annual Green Buildings Conference and Exhibition, 17-19 November 1996, San Diego, California, pp. 1-23.

Maroni, M., Seifert, B. and Lindvall, T. (1995) Indoor Air Quality a Comprehensive Reference Book, Amsterdam, Elsevier Science.

McKinley, R.K., Manku-Scott. T., Hastings, A.M., French, D.P. and Baker, R. (1997) "Reliability and Validity of a New Measure of Patient Satisfaction With Out of Hours Primary Medical Care in the United Kingdom: Development of a Patient Questionnaire", British Medical Journal, Vol. 314: 7075, pp. 193-198.

Oanh, N.T.K. and Hung, Y.T. (2005) "Indoor Air Pollution Control", Advanced Air and Noise Pollution Control, Vol. 2, Ed. Wang, L.K., Pereira, N.C. and Hung, Y.T., Totowa, New
Jersey, A.B.D., Humana Press, pp. 237-271.

Ohura, T., Amagi, T., Shen, X.L., Zhang, P. and Zhu, L. (2009) "Comperative Study on Indoor Air Quality in Japan and China: Characteristics of Residential Indoor and Outdoor VOCs", Atmospheric Environment, Vol. 43: 40, pp. 63526359.

Pearson, D. (1989) The Natural House Book, London, Conran Octopus Limited.

Sandmeyer, E. (1982) "Cylic Hydrocarbons", Patty's Industrial Hygiene and Toxicology, Vol. 2, Ed. Clayton, G.D. and Clayton, F.E., Wiley, New York, A.B.D., pp. 3253-3431.

Spellman, F.R. (2008) The Science of Air: Concepts and Applications, Boca Raton, CRC Press.

Şenyiğit, A., Dalgıç, A. and Kavak, O. (2004) "Asbestin Sağlığa Etkisi", Dicle Tıp Dergisi, Vol. 31: 4, pp. 48-52.

T.C. Sağlık Bakanlığı Temel Sağ|ık Hizmetleri Genel Müdürlüğü (2010) Türkiye Kronik Hava Yolu Hastalıklarını Önleme ve Kontrol Programı, Ankara, Anıl Matbaacılık.

Tecer, L.H. (2011) "Hava Kirliliği ve Sağlığımız", Bilim ve Aklın Aydınlığında Eğitim" No. 135, pp. 15-29.

Vaizoğlu, S.A., Tekbaş, Ö.F. and Evci, D. (2000) "Kapalı Ortam Hava Kalitesi, Sağlığa Etkisi", Sted, Vol. 9: 11, pp. 1-5.

Vural, S.M. and Balanlı, A. (2005) "Yapı Ürünü Kaynaklı iç Hava Kirliliği Risk Değerlendirmede Ön Araştırma”, Megaron YTÜ Mimarlık Fakültesi Dergisi, Vol. 1: 1, pp. 28-39.

Wolverton, B.C., Johnson, A. and Bounds, K. (1989) Interior Landscape Plants for Indoor Air Pollution Abatement NASA/ALCA Final Report, Davidsonville, Maryland, Plants for Clean Air Council.

Wolverton, B.C., McDonald, R.C. and Watkins Jr., E.A. (1984) "Foliage Plants for Removing Indoor Air Pollutants From Energy-Efficient Homes", Economic Botany, Vol. 38: 2, pp. 224-228.

Yıldırım, K. (2013) “Bitkilerin İç Mekân Kirleticileri Üzerindeki Etkileri", İçmimar Dergisi, No. 28, pp. 107-115.

Yildirim, K. and Ünlü, F. (2013) 'Determination of Users' Knowledge on the Impact of Organic Chemicals in Interior Elements on Health: Ankara/Turkey Sample", Open Environmental Sciences, Vol. 7, pp. 32-40.

Yildirim, K., Hidayetoglu, M.L. and Capanoglu, A. (2011) "Effects of Interior Colors on Mood and Preference: Comparisons of Two Living Rooms", Perceptual and Motor Skills, Vol. 112: 2, pp. 509-524.

Yildirim, K., Hidayetoglu, M.L. and Sen, A. (2012) "Effects on Sustainability of Various Skylight Systems in Buildings with an Atrium", Smart and Sustainable Built Environment, Vol. I: 2, pp. 139-152.

Yurtseven, E. (2007) “iki Farklı Coğrafi Bölgedeki Illköğretim Okullarında İç Ortam Havasının İnsan Sağlığına Etkileri Yönünden Değerlendirilmesi", Doctoral Thesis, İstanbul, İstanbul Üniversitesi, Sağlık Bilimleri Enstitüsü.

\section{Internet References}

1. CIDA http://accredit-id.org/wp-content/uploads/2010/03/Professional-Standards-2014.pdf [Accessed 14.07.2014]. 